\title{
Virulence factors of Actinobacillus actinomycetemcomitans: other putative factors
}

\section{Fatores de virulência do Actinobacillus actinomycetemcomitans: outros possíveis fatores}

\author{
Mario Julio AVILA-CAMPOS* \\ Maria Regina Lorenzetti SIMIONATO* \\ Silvana CAI* \\ Márcia Pinto Alves MAYER* \\ José Luiz DE LORENZO* \\ Flávio ZELANTE**
}

\begin{abstract}
AVILA-CAMPOS, M. J.; SIMIONATO, M. R. L.; CAI, S.; MAYER, M. P. A.; DE LORENZO, J. L.; ZELANTE, F. Virulence factors of Actinobacillus actinomycetemcomitans: other putative factors. Pesq Odont Bras, v. 14, n. 1, p. 05-11, jan./mar. 2000.

Actinobacillus actinomycetemcomitans is implicated as the causative agent of localized juvenile periodontitis. This organism possesses a large number of virulence factors with a wide range of activities and also interfere with tissue repair. Fifty isolates of $A$. actinomycetemcomitans from 20 periodontal patients were examined to evaluate other putative virulence factors. In this study, the capsule, DNase, coagulase, fibrinolysin, proteolytic, haemolysin and bacteriocin production, haemagglutination, serum sensitivity, epithelial cells attachment, hydrophobicity and virulence of the $A$. actinomycetemcomitans isolates were evaluated. All the isolates were resistant to the different tested sera. $70 \%$ to $94 \%$ were alpha-haemolytics and agglutinated all blood types. Most of isolates produced antagonistic substances and they had a low hydrophobicity. None of the isolates was pathogenic for mice. Little is known as to wether these factors may act in the development of periodontal disease, and further studies are required for an application in pathogenic and systematic terms.
\end{abstract}

UNITERMS: Actinobacillus actinomycetemcomitans; Virulence factors; Periodontal disease.

\section{INTRODUCTION}

Actinobacillus actinomycetemcomitans, a rodshaped Gram-negative coccobacillus, is a pathogen in several nonoral diseases and a putative pathogen in periodontal diseases ${ }^{21,28}$. This organism has been diagnosed as the primary etiological agent associated with localized juvenile periodontitis, and it has also been recognised as a major periodontopathogenic organism. There is great interest in determining and characterising those factors which enable this organism to colonise the oral cavity, invade the periodontal tissues, overcome the host's defences and be transmitted to other host ${ }^{27}$.

A. actinomycetemcomitans possesses a large number of virulence factors, which may be relevant in the pathogenesis of periodontal disease, such as leukotoxin, collagenase, endotoxin, and a fibroblast-inhibiting factor. In addition, $A$. actinomycetemcomitans produces a soluble heat labile factor that inhibits growth and proliferation of Actinomyces viscosus and Streptococcus sanguis, organisms closely associated with plaque formation ${ }^{4}$.

Its adhesion to epithelial cells and tooth surfaces is frequently mediated by fimbrae, specific adhesins or microvesicles which define, in part, the range of ecological niches that a given strain can inhabit ${ }^{28}$. Bacteria carrying fimbriae possess an important virulence factor mediating adherence to epithelial cell surfaces, and use it as an initial step in bacterial colonization and invasion ${ }^{18}$. The goal of this study was to evaluate some other putative virulence factors in A. actinomycetemcomitans isolated from patients with adult periodontitis.

\footnotetext{
* Professor, Doctorate Degree; **Professor and Chair - Department of Microbiology, Institute of Biomedical Sciences, University of São Paulo.
} 
AVILA-CAMPOS, M. J.; SIMIONATO, M. R. L.; CAI, S.; MAYER, M. P. A.; DE LORENZO, J. L.; ZELANTE, F. Virulence factors of Actinobacillus actinomycetemcomitans: other putative factors. Pesq Odont Bras, v. 14, n. 1, p. 05-11, jan./mar. 2000.

\section{MATERIALS AND METHODS Bacteria}

Fifty strains of $A$. actinomycetemcomitans obtained from 20 patients with adult periodontitis at the Clinic of Periodontology, Dental School, University of São Paulo, were examined and selected by specialists. The patients' ages ranged 25-40 years, all exhibited clinical and radiographic evidences of alveolar bone loss confined to molar and/or incisive teeth, and periodontal pocket depth equal to or exceeding $5 \mathrm{~mm}$. None had received antibiotics for at least 3 months prior to the collection of the samples. Briefly, supragingival plaque was removed, and subgingival bacterial samples were taken from either molar or incisor teeth mesial surfaces using two fine sterile paper points (Dentsply Ind. Co. Ltda., R.J., Brazil). These were inserted into periodontal pockets for $60 \mathrm{sec}-$ onds and then transferred to tubes containing $2.0 \mathrm{ml}$ of Ringer-PRAS solution ( $\mathrm{pH} 7.2)$, under $\mathrm{CO}_{2}$ flux. After dispersion by a Vortex mixer, aliquots of $0.1 \mathrm{ml}$ of undiluted and $10^{-3}$ diluted sample solution were plated on a selective trypticase soy-serum-bacitracin-vancomycin (TSBV) agar $^{22}$. Samples were cultured within two hours after they had been collected. After $72 \mathrm{~h}$ in anaerobiosis $(90 \%$ $\mathrm{N}_{2}+10 \% \mathrm{CO}_{2}$ ), at $37^{\circ} \mathrm{C}$, suspected colonies were subcultured and confirmed as belonging to $A$. actinomycetemcomitans if they produced translucent colonies with a starlike inner structure, gram-negative coccobacilli, catalase positive, and if they did not ferment lactose, starch, sucrose, and trehalose ${ }^{23}$. Two, and in some cases up to three, colonies of $A$. actinomycetemcomitans were selected from each subgingival sample. All isolates were stored in $20 \%$ glycerol at $-70^{\circ} \mathrm{C}$.

\section{Detection of capsules}

Capsules were detected by negative staining with Indian ink. A drop of a $24 \mathrm{~h}$ broth culture (late exponential phase) was mixed with a drop of $10 \%$ $(\mathrm{w} / \mathrm{v})$ glucose and a drop of Indian ink on a microscope slide, placing a coverslip on the mixture and blotting off the excess, and examined under light microscopy.

\section{DNase production}

Bacteria were grown in Brain Heart Infusion broth (BHI-Difco) for $48 \mathrm{~h}$ and subcultured in spots on DNase agar. The inoculated plates were incubated under microaerophilic conditions (candle method), at $37^{\circ} \mathrm{C}$, for $48 \mathrm{~h}$. After growth, $0.1 \mathrm{ml}$ of $1 \mathrm{~N}-\mathrm{HCl}$ solution was added on colonies. A positive result showed a clear zone around the growth.

\section{Coagulase production}

Coagulase production was tested in pooled human or rabbit plasma. $0.5 \mathrm{ml}$ of undiluted plasma with an equal volume of a 24-48 h broth culture was mixed, and incubated under microaerophilia, $\left(37^{\circ} \mathrm{C}, 24 \mathrm{~h}\right)$. A positive result was indicated by definite clot formation. A granular or ropy growth was regarded as doubtful and the organism was retested.

\section{Fibrinolysin production}

$0.5 \mathrm{ml}$ of undiluted human plasma with $0.5 \mathrm{ml}$ of a 24-48 h broth culture was mixed, and incubated at $37^{\circ} \mathrm{C}$. A positive result was observed when human fibrin was lysed, destroying the coagulated plasma.

\section{Proteolytic activity}

Non-specific proteases production was observed in BHI broth or agar containing $1 \%$ gelatine or casein, respectively. Media were inoculated and incubated (microaerophilia, $37^{\circ} \mathrm{C}, 48 \mathrm{~h}$ ). A positive result was indicated by liquefying and by a clear zone around the growth, respectively.

\section{Haemolysin production}

Human A, B, AB, O (Rh-positive and Rh-negative) blood, sheep and rabbit blood at $5 \%$, were tested. $20 \mu \mathrm{l}$ aliquots of each culture were inoculated on blood agar plates and incubated (microaerophilia, $37^{\circ} \mathrm{C}, 48 \mathrm{~h}$ ). A positive result was shown as a haemolytic halo around the growth.

\section{Haemagglutination}

Human A, B, AB, O (Rh-positive and Rh-negative), and sheep blood were collected weekly and stored at $10 \%(\mathrm{v} / \mathrm{v})$ in Alsever's solution at $4^{\circ} \mathrm{C}$. Erythrocytes were washed three times with phosphate buffered saline (PBS, pH 7.2) at $2.500 \mathrm{rpm}$, 10 min, and suspended in PBS to a concentration of $2 \%(\mathrm{v} / \mathrm{v})$. Bacteria were grown for $24 \mathrm{~h}$ in $\mathrm{BHI}$, washed three times in PBS, and suspended to a concentration of $5 \times 10^{8}$ bacteria/ml as estimated by a McFarland scale. Haemagglutination (HA) was tested qualitatively by mixing $50 \mu$ of bacterial suspension with $50 \mu \mathrm{l}$ of erythrocytes. When this screening test gave positive results, a quantitative test was performed; serial two-fold dilutions of the bacterial suspensions in $50 \mu \mathrm{l}$ PBS were made in V-bottomed microtiter plates. $50 \mu 1$ of erythrocyte suspension was added to each dilution, then the plate was gently shaken and kept overnight at $4^{\circ} \mathrm{C}$. Haemagglutination titres were expressed as the re- 
AVILA-CAMPOS, M. J.; SIMIONATO, M. R. L.; CAI, S.; MAYER, M. P. A.; DE LORENZO, J. L.; ZELANTE, F. Virulence factors of Actinobacillus actinomycetemcomitans: other putative factors. Pesq Odont Bras, v. 14, n. 1, p. 05-11, jan./mar. 2000.

ciprocal of the highest bacterial dilution that showed haemagglutination.

\section{Serum sensitivity}

Serum sensitivity was tested in human A, B, $\mathrm{AB}, \mathrm{O}$ (Rh-positive and Rh-negative) sera at concentrations of $10 \%, 50 \%$ and $100 \%(\mathrm{v} / \mathrm{v})$ in PBS. Bacteria were grown in microaerophilia, for $48 \mathrm{~h}$, and washed once in PBS. Serum was inoculated with $10^{6} \mathrm{CFU}$ and incubated for two hours under microaerophilia. Inactivated $10 \%$ and $50 \%(\mathrm{v} / \mathrm{v})$ sera $\left(60 \mathrm{~min}, 56^{\circ} \mathrm{C}\right)$ were also used as controls. Viable counts were made on BHI agar after incubation of $48 \mathrm{~h}$.

\section{Bacteriocin-like substances}

Isolates were tested for their inhibitory activity against themselves and against $A$. actinomycetemcomitans ATCC 29522, ATCC 29523, and FDC Y4, Streptococcus mutans ATCC 25175, S. sanguis ATCC 10556, Fusobacterium nucleatum ATCC 25586 and Prevotella intermedia ATCC 25611. Bacteriocinogenic activity was performed by the double layer method ${ }^{5}$. Inoculum for evaluation of bacteriocin-producing capacity was prepared in BHI broth. With a standard platinum wire, cultures of $24 \mathrm{~h}$ were inoculated in 5 equidistant spots on BHI agar (1.5\%). After incubation at $37^{\circ} \mathrm{C}$ for $48 \mathrm{~h}$, cells were killed by exposure to chloroform steam for $30 \mathrm{~min}$. Residual chloroform was allowed to evaporate and then they were overlayed with $3.5 \mathrm{ml}$ of BHI soft agar (0.7\%) inoculated with a culture of the indicator strain. After $48 \mathrm{~h}$ of incubation the presence of bacteriocin-like substances was evaluated. Tests for bacteriophages detection were also performed.

\section{Epithelial cells attachment}

Epithelial cells were obtained by gently scraping the oral mucosal surfaces from a healthy adult donor (female, A Rh+). The cells were suspended in PBS and washed twice by centrifugation. The suspension was adjusted to approximately $2 \times 10^{5}$ cells based on direct count in Neubauer chamber. A. actinomycetemcomitans were grown in BHI broth with $10 \mu \mathrm{Ci} / \mathrm{ml}$ of ${ }^{3} \mathrm{H}$-thymidine (Sigma), under microaerophilia, at $37^{\circ} \mathrm{C}$ for $48 \mathrm{~h}$. The organisms were harvested by centrifugation $(3,500 \mathrm{rpm}$, $4^{\circ} \mathrm{C}, 20 \mathrm{~min}$ ) and washed twice with PBS, and then they were adjusted to $1 \times 10^{9} \mathrm{UFC}$, standardization was accomplished by relating the $\mathrm{OD}_{660 \mathrm{~nm}}$. Equal standardized volumes of epithelial cells and bacteria were mixed at rotation $\left(10 \mathrm{rpm}, 37^{\circ} \mathrm{C}, 60 \mathrm{~min}\right)$. These suspensions were washed with $100 \mathrm{ml}$ PBS on $8 \mu \mathrm{m}$ membrane filters (Millipore, Corp., Massachusetts) to remove free bacterial cells. The membranes with retained attached bacteria to epithelial cells were dried at room temperature and transferred to scintillation vials to measure the radioactivity present. Bacterial inocula control were always included and all assays were run in triplicate. The ability of attachment was expressed in percentage of adhered bacteria to epithelial cells.

\section{Hydrophobicity assay}

The relative surface hydrophobicity of bacteria was measured by their interaction with n-hexadecane (Sigma) $)^{8,20}$. Briefly, the organisms were grown in BHI, at $37^{\circ} \mathrm{C}$, for $48 \mathrm{~h}$ and then, washed twice in PUM buffer ( $\mathrm{pH} 7.1)$ to an $\mathrm{OD}_{660 \mathrm{~nm}}$ of 0.16 . Then, $3 \mathrm{ml}$ of bacterial suspension was placed in a tube, and hexadecane $(400 \mu \mathrm{l})$ was added. The samples were mixed with a vortex mixer for two 30-second periods. The $\mathrm{OD}_{660 \mathrm{~nm}}$ of the aqueous phase was measured, and the values were expressed as percentage of bacteria adsorbed to hexadecane and remaining in the aqueous phase. Hydrophobicity values were recorded as the mean of triplicate assays for each isolate.

\section{Virulence studies}

The virulence of the A. actinomycetemcomitans was measured by bacterial injection into subcutaneous tissue of mice ${ }^{26}$.

\section{RESULTS}

\section{Biochemical characteristics}

Fifty isolates were recovered and analysed as to some bacterial factors. All were capsulated and catalase-positive, $8 \%$ producing indole and $14 \%$, gas from glucose, and $86 \%$ reduced $\mathrm{NO}_{3}$ to $\mathrm{NO}_{2}$, $18 \%$ hydrolyzed arginin and $8 \%$, casein. Isolates neither had motility, produced oxidase, $\mathrm{H}_{2} \mathrm{~S}$, DNase, coagulase, nor produced hydrolysis of urea, ONPG, starch, aesculin or gelatin. Also, isolates were not resistant to $56^{\circ} \mathrm{C}$ or $60^{\circ} \mathrm{C}$, for 30 min.

\section{Fibrinolytic and haemolytic activity, and haemagglutination}

Only ten isolates were capable to produce lysis of human fibrin in 1 to $24 \mathrm{~h}$. Most isolates $(70 \%$ to 94\%) showed a partial haemolysis on all blood types tested. In the qualitative test, most of the isolates strongly agglutinated all blood types. Few isolates showed haemagglutination titers of 4 or 8 (Table 1). 
AVILA-CAMPOS, M. J.; SIMIONATO, M. R. L.; CAI, S.; MAYER, M. P. A.; DE LORENZO, J. L.; ZELANTE, F. Virulence factors of Actinobacillus actinomycetemcomitans: other putative factors. Pesq Odont Bras, v. 14, n. 1, p. 05-11, jan./mar. 2000.

\section{Serum sensitivity}

All the isolates were resistant at three different concentrations of different human sera.

\section{Bacteriocinogenic activity}

The inhibitory activity of isolates was tested against themselves and against seven reference strains. 13 of the 50 tested isolates showed antagonistic activity against themselves or against the reference strains. Isoantagonism and heteroantagonism was observed in 9 and $4 A$. actinomycetemcomitans isolates, respectively. No inhibition was observed against $S$. mutans, $F$. nucleatum or $P$. intermedia.

\section{Attachment to epithelial cells and cell surface hydrophobicity}

The radioassay with mixtures of $\left[{ }^{3} \mathrm{H}\right.$-thymidine] -labeled A. actinomycetemcomitans and epithelial cells showed a large number of isolates attached. Also, the cell surface hydrophobicity of the isolates is also shown in Table 2. The majority of them had low hydrophobicity, and $75 \%$ to $100 \%$ of their cells remained in aqueous phase after hexadecane partitioning. Only one isolate (no. 16) was highly hydrophobic. Isolates no. 30 and 71 were relatively hydrophobic and their cells adsorbed to hexadecane $(55.2 \%$ and $60.9 \%$, respectively).

\section{Virulence study}

None of the isolates showed exceptional patho-

TABLE 1 - Haemolysis and haemagglutination of human and animal erythrocytes by A. actinomycetemcomitans isolates.

\begin{tabular}{c|c|c|c|c|c|c}
\hline \hline \multirow{2}{*}{ Blood } & \multirow{2}{*}{$\begin{array}{c}\text { \% hae- } \\
\text { molysis }\end{array}$} & \multicolumn{5}{|c}{$\begin{array}{c}\text { \% positive at each } \\
\text { haemagglutination titer }\end{array}$} \\
\cline { 4 - 7 } Human & & 0 & $<2$ & 2 & 4 & 8 \\
\hline A, Rh+ & 94 & 20 & 26 & 52 & 2 & 0 \\
\hline A, Rh- & 92 & 42 & 12 & 46 & 0 & 0 \\
\hline B, Rh+ & 88 & 16 & 40 & 40 & 2 & 2 \\
\hline B, Rh- & 88 & 20 & 24 & 38 & 18 & 0 \\
\hline O, Rh+ & 88 & 34 & 12 & 50 & 4 & 0 \\
\hline O, Rh- & 84 & 24 & 20 & 40 & 16 & 0 \\
\hline AB, Rh+ & 94 & 18 & 36 & 38 & 6 & 2 \\
\hline AB, Rh- & 82 & 36 & 32 & 32 & 0 & 0 \\
\hline Animal & & & & & & \\
\hline Sheep & 70 & 22 & 24 & 38 & 14 & 2 \\
\hline rabbit & 76 & 21 & 14 & 36 & 10 & 0 \\
\hline \hline
\end{tabular}

genicity for mice, nor was a specific mouse strain susceptible to infection with these bacteria. Ten days after infection only 11 isolates caused ulcerated and/or pus-filled abscesses which were large, round and dome-shaped, with approximately $6.0 \pm 2.5 \mathrm{~mm}$ in diameter. Reference strains $A$. actinomycetemcomitans ATCC 29523 and FDC Y4 produced abscesses in at least two mice strains (Table 3).

TABLE 2 - Epithelial cell attachment and hydrophobic characteristics of $A$. actinomycetemcomitans.

\begin{tabular}{|c|c|c|c|c|c|}
\hline $\begin{array}{c}\text { Isolate } \\
\text { (no.) }\end{array}$ & $\begin{array}{l}\% \text { cell } \\
\text { attach- } \\
\text { ment }^{\mathrm{a}}\end{array}$ & $\begin{array}{c}\% \text { water } \\
\text { phase }^{\mathrm{a}}\end{array}$ & $\begin{array}{c}\text { Isolate } \\
\text { (no.) }\end{array}$ & $\begin{array}{l}\% \text { cell } \\
\text { attach- } \\
\text { ment }^{\mathrm{a}}\end{array}$ & $\begin{array}{c}\text { \% water } \\
\text { phase }^{\mathrm{a}}\end{array}$ \\
\hline 1 & 86.10 & 83.5 & 44 & 95.98 & 91.5 \\
\hline 2 & 83.10 & 100.0 & 45 & 80.74 & 94.3 \\
\hline 3 & 87.85 & 87.8 & 46 & 91.20 & 94.3 \\
\hline 4 & 85.42 & 96.1 & 49 & 97.88 & 94.3 \\
\hline 5 & NT & 82.8 & 50 & 85.09 & 75.0 \\
\hline 6 & 87.08 & 79.2 & 55 & 98.36 & 98.1 \\
\hline 9 & 84.33 & 81.5 & 56 & 91.01 & 94.6 \\
\hline 11 & 98.53 & 100.0 & 57 & 89.09 & 90.0 \\
\hline 12 & 80.69 & 77.3 & 59 & 87.70 & 100.0 \\
\hline 13 & 79.79 & 100.0 & 60 & NT & 100.0 \\
\hline 14 & 84.14 & 80.0 & 63 & 87.35 & 77.9 \\
\hline 16 & 86.89 & 24.9 & 69 & 76.33 & 100.0 \\
\hline 19 & 92.99 & 95.0 & 70 & 87.60 & 92.3 \\
\hline 20 & 83.80 & 80.8 & 71 & 93.60 & 60.9 \\
\hline 21 & 77.59 & 92.1 & 75 & 82.43 & 94.1 \\
\hline 24 & 62.13 & 89.9 & 77 & 82.21 & 100.0 \\
\hline 25 & 48.93 & 98.9 & MP1 & 74.15 & 77.0 \\
\hline 26 & NT & 94.2 & MP2 & NT & 99.1 \\
\hline 27 & 81.06 & 88.2 & MP3 & NT & 88.7 \\
\hline 28 & 75.84 & 89.6 & MP5 & 95.49 & 90.0 \\
\hline 30 & 82.20 & 55.2 & MP8 & 99.87 & 71.0 \\
\hline 35 & 68.94 & 84.3 & MP9 & 95.38 & 77.7 \\
\hline 37 & 65.08 & 97.1 & $29522 *$ & 88.69 & 77.3 \\
\hline 38 & 79.41 & 86.7 & $29523 *$ & NT & 92.5 \\
\hline 40 & 73.32 & 82.0 & $Y 4 * *$ & 83.19 & 84.0 \\
\hline 42 & 78.40 & 87.9 & & & \\
\hline
\end{tabular}

aMean; *ATCC; **FDC; NT: Not tested 
AVILA-CAMPOS, M. J.; SIMIONATO, M. R. L.; CAI, S.; MAYER, M. P. A.; DE LORENZO, J. L.; ZELANTE, F. Virulence factors of Actinobacillus actinomycetemcomitans: other putative factors. Pesq Odont Bras, v. 14, n. 1, p. 05-11, jan./mar. 2000.

\section{DISCUSSION}

All fifty isolated A. actinomycetemcomitans possessed capsule and produced catalase; these observations have also been reported by other investigators ${ }^{1,23}$. Polysaccharide capsula has been considered as a major factor in the attachment to the oral mucosa, and it has also been used to sorotype these organisms ${ }^{29}$.

The majority of $A$. actinomycetemcomitans isolates was alpha-haemolytic. However, it is still not clear to what extent alpha- and beta-haemolysin are different from each other; it has been speculated that beta-haemolysin might be a cell-bound form of alpha-haemolysin ${ }^{19}$. No specificity between haemolysins produced by the isolates and any blood type was observed. However, it is not known if haemolysin or fibrinolysin contributes to the pathogenicity or virulence of some A. actinomycetemcomitans strains ${ }^{2}$. The pathogenic character of A. actinomycetemcomitans is poorly understood and an abundance of extracellular products are suspected of contributing to its virulence, e.g., leukotoxin ${ }^{25}$. Most of the isolates producing abscesses were active against Balb/c mice strain (Table 3). Also, A. actinomycetemcomitans ATCC

TABLE 3 - Pathogenic action of A. actinomycetemcomitans on inbred mice strains.

\begin{tabular}{c|c|c|c|c|c}
\hline \hline \multirow{2}{*}{$\begin{array}{c}\text { Bacteria } \\
(\text { no. })\end{array}$} & \multicolumn{5}{|c}{ Inbred strains } \\
\cline { 2 - 6 } & Balb/c & C57Bl/6 & A/Sn & B10.A & cAF1 \\
\hline 3 & + & - & - & - & - \\
\hline 8 & - & - & + & - & - \\
\hline 11 & + & - & - & - & - \\
\hline 20 & - & - & + & - & - \\
\hline 27 & - & + & - & - & - \\
\hline 34 & + & + & - & - & - \\
\hline 36 & + & - & - & - & - \\
\hline 40 & - & - & - & + & - \\
\hline 48 & - & - & - & + & - \\
\hline 50 & + & - & - & - & - \\
\hline 55 & + & - & - & - & - \\
\hline $29522^{\mathrm{b}}$ & + & - & - & - & - \\
\hline $29523^{\mathrm{b}}$ & - & + & + & + & + \\
\hline $\mathrm{Y}^{\mathrm{c}}$ & - & - & + & + & - \\
\hline \hline
\end{tabular}

$(+)$ abscess formation in the injection site.

b A. actinomycetemcomitans ATCC.

c $A$. actinomycetemcomitans FDC.
29523 was more pathogenic, producing abscesses in 4 different strains of mice.

A. actinomycetemcomitans is resistant to the serum bactericidal activity ${ }^{16}$. The resistance to serum killing may be a relevant factor for the utilized mice model. Isolates did not appear to affect their general health, neither to promote weight loss or gain. Historically, animal models have been invaluable for the establishment of the aetiology, pathogenicity and prevention of human infectious diseases ${ }^{7}$. Likewise, appropriate animal models are necessary to determine the combined effect of these virulence factors expressed in vivo, so as to take into account their possible competing effects ${ }^{27}$. There are few reports about abscess formation by this microbial group on inbred strains of mice ${ }^{3}$.

Periodontopathogenic bacteria may invade the gingival connective tissue, in part because no effective fibrin barrier is formed around the infecting organisms. Some black-pigmented rods have long been known to possess fibrinolytic activity. This fibrinolysin is a non-specific protease which shows activity against several proteinaceous substrates ${ }^{14}$. Most of the isolates were clearly more active to produce HA and it may reflect a general ability to adhere to host tissues.

Bacterial antagonism may also be determinant in oral colonization by microorganisms, e.g., a proteinaceous bacteriocin-like compound from black-pigmented rods, called melaninocin, inhibits non-melanocin-producing black-pigmented rods, Capnocytophaga, S. mitis, and Actinomyces species $^{15}$. In addition, it was observed that $4 A$. actinomycetemcomitans produced antagonist substances against $S$. mutans, Gram-positive organisms and other important microorganisms in the oral ecology. Bacteriocin synthesis is claimed to be an unstable characteristic since some strains lose and recover the capacity to produce it, which is understandable since it is normally expressed by a small proportion of the bacterial population ${ }^{16}$. The frequency of bacteriocin-producing among the tested isolates was very low, when compared to other studies ${ }^{24}$, and it might be explained by regional differences among A. actinomycetemcomitans. However, the genetic basis of its production has not yet been identified, and the mechanism of attachment to specific cell receptors is unknow ${ }^{9}$. This and further studies may have taxonomic interest and also may help to understand the role that these substances play in human oral microbial ecology.

It is generally accepted that hydrophobicity is important in the bacteria-host cells interaction, 
AVILA-CAMPOS, M. J.; SIMIONATO, M. R. L.; CAI, S.; MAYER, M. P. A.; DE LORENZO, J. L.; ZELANTE, F. Virulence factors of Actinobacillus actinomycetemcomitans: other putative factors. Pesq Odont Bras, v. 14, n. 1, p. 05-11, jan./mar. 2000.

and it may also be associated to the microbial coaggregation ${ }^{13}$. In this study, it was observed that A. actinomycetemcomitans surface showed hydrophilic properties ${ }^{26}$. On the other hand, hydrophobic characteristics of $A$. actinomycetemcomitans have also been observed ${ }^{10,12}$. However, the conflicting data may be due to methodological differences such as conditions or phases of bacterial growth, hydrocarbon or $\mathrm{pH}^{20}$. In addition, this study showed no correlation between hydrophobicity of A. actinomycetemcomitans isolates and its attachment to oral epithelial cells.

The ability of $A$. actinomycetemcomitans to agglutinate different erythrocytes may be important in an in vivo situation of intra-oral or intra-abdominal infection, where bacterial adherence to epithelial cells may prevent clearance of bacteria from these cavities. Centrifugation in Percoll density gradients has recently been found to readily separate epithelial cells from unattached bacteria, and this has resulted in the development of a simple assay to quantify the radiolabeled-bacteria attachment to epithelial cells ${ }^{6}$. These results reflect a high-affinity interaction between $A$. actinomycetemcomitans and epithelial surfaces, and its ecological significance may therefore be questioned. The existence of multiple binding sites on experimental salivary pellicles with widely differing affinities has been previously reported for the Streptococcus species attachment ${ }^{17}$. The nature of adhesins which mediate a high-affinity on binding A. actinomycetemcomitans to oral epithelial cells has not been established. Its attachment has been found to be mediated by proteinaceous adhesins, many of which have lectin-like properties ${ }^{11}$. Certainly, further studies are required for a functional, genetical and molecular characterization of the virulence factors in order to allow for a systematic interpretation of the pathogenicity.

\section{ACKNOWLEDGMENTS}

The authors want to thank Andemir da Silva and João Paulo Ribeiro for their technical assistance. This study was supported in part by Fundação de Amparo à Pesquisa do Estado de São Paulo (FAPESP), Grant Proc. no. 93/0056-0.

AVILA-CAMPOS, M. J.; SIMIONATO, M. R. L.; CAI, S.; MAYER, M. P. A.; DE LORENZO, J. L.; ZELANTE, F. Fatores de virulência do Actinobacillus actinomycetemcomitans: outros possiveis fatores. Pesq Odont Bras, v. 14, n. 1, p. 05-11, jan./mar. 2000.

Actinobacillus actinomycetemcomitans está implicado como o agente etiológico da periodontite juvenil localizada. Este organismo possui inúmeros fatores de virulência que podem interferir no reparo tissular. 50 isolados de A. actinomycetemcomitans de pacientes com periodontite foram examinados para avaliar outros possiveis fatores de virulência. Neste estudo, foi avaliada a produção de cápsula, DNase, coagulase, fibrinolisina, atividade proteolítica, hemolisina e bacteriocina, assim como hemaglutinação, sensibilidade ao soro, aderência às células epiteliais, hidrofobicidade e virulência de $A$. actinomycetemcomitans. Todos os isolados foram resistentes para todos os tipos de soro utilizados. $70 \%$ a $94 \%$ dos isolados foram alfa-hemolíticos e aglutinaram todos os tipos sanguíneos. A maioria dos isolados produziu substâncias antagonistas e apresentaram baixa hidrofobicidade. Nenhum dos isolados foi patogênico para camundongos. Pouco se sabe, sobre a ação e como esses fatores podem agir no desenvolvimento da doença periodontal, sendo necessários estudos adicionais para uma aplicação em termos de sistemática e de patogênese.

Unitermos: Actinobacillus actinomycetemcomitans; Fatores de virulência; Doença periodontal.

\section{BIBLIOGRAPHIC REFERENCES}

1. AVILA-CAMPOS, M. J.; CARVALHO, M. A. R.; ZELANTE, F. Distribution of biotypes and antimicrobial susceptibility of Actinobacillus actinomycetemcomitans. Oral Microbio Immunol v. 10, n. 1, p. 382-384, May 1995.

2. AVILA-CAMPOS, M. J. Haemolytic activity of Actinobacillus actinomycetemcomitans strains on different blood types. Rev Inst Med Trop São Paulo. v. 37, n. 3, p. 215-217, May 1995.

3. AVILA-CAMPOS, M. J.; SILVA, A. Pathogenic action of Actinobacillus actinomycetemcomitans on inbred strains of mice. Rev Microbiol v. 26, n. 2, p. 112-116, Jun. 1995.

4. BAEHNI, P. C.; TSAI, C. C.; MC ARTHUR, W. P. et al. Leucotoxic activity in different strains of the Bacterium actinomycetemcomitans isolated from juvenile periodontitis in man. Arch Oral Biol v. 26, n. 1, p. 271-276, Mar. 1981.

5. BOOTH, S. J.; JOHSON, J. L.; WILKINS, T. D. Bacteriocin production by strains of Bacteroides isolated from human feces and the role of these strains in the bacterial ecology of the colon. Antimicrob Agents Chemother v. 11, n. 4, p. 718-724, Dec. 1977.

6. CHILDS, W. C.; GIBBONS, R. J. Use of Percoll gradients for 
AVILA-CAMPOS, M. J.; SIMIONATO, M. R. L.; CAI, S.; MAYER, M. P. A.; DE LORENZO, J. L.; ZELANTE, F. Virulence factors of Actinobacillus actinomycetemcomitans: other putative factors. Pesq Odont Bras, v. 14, n. 1, p. 05-11, jan./mar. 2000.

assays of bacterial attachment to epithelial cells. J Dent Res (Spec Issue) v. 65, n. 2. p. 736, Abst. 99, 1986.

7. CLARK, W. B.; MAGNUSSON, I.; ABEE, C. et al. Natural occurrence of black-pigmented Bacteroides species in the gingival crevice of the squirrel monkey. Infect Immun v. 56, n. 3, p. 2392-2399, Apr. 1988.

8. GIBBONS, R. J.; ETHERDEN, I. Comparative hydrophobicities of oral bacteria and their adherence to salivary pellicles. Infect Immun v. 41, n. 3, p. 1190-1196, May 1983

9. HAMMOND, B. F.; LILLARD, S. E.; STEVENS, R. H. A bacteriocin of Actinobacillus actinomycetemcomitans. Infect Immun v. 55, n. 3, p. 686-691, Mar. 1987.

10. HOLM, A.; KALFAS, S. Cell surface hydrophobicity and electrokinetic potential of Actinobacillus actinomycetemcomitans and Haemophilus aphrophilus. Oral Microbiol Immunol v. 6, n. 4, p. 236-240, Jun. 1991.

11. JONES, G. W.; ISACSSON, R. E. Proteinaceous bacterial adhesins and their receptors. Crit Rev Microbiol v. 10, n. 3, p. 229-260, 1983.

12. KOZLOVSKY, A.; METZGER, Z.; ELI, I. Cell surface hydrophobicity of Actinobacillus actinomycetemcomitans Y4. J Clin Periodontol. v. 14, n. 4, p. 370-372, 1987.

13. KRISHNA, M. M.; POWELL, N. B. L.; BORRIELLO, S. P. Cell surfaces properties of Clostridium difficile: haemagglutination, relative hydrophobibity and charge. J Med Microbiol v. 44, n. 11, p. 115-123, May 1996.

14. MASHIMO, P. A.; SLOTS, J. Fibrinolytic activity of black-pigmented Bacteroides species. IADR Progr \& Abst v. 62, n. 1, p. 123, Oct. 1983.

15. NAKAMURA, T.; FUJIMURA, S.; OBATA, N.; YAMAZAKI, N. Bacteriocin-like substance (melaninocin) from oral Bacteroides melaninogenicus. Infect Immun v. 31, n. 4, p. 28-32, Jun. 1981.

16. OLIVEIRA, R. G. B.; DROZDOWICZ, A. Bacteriocin in the genus Azospirillum. Rev Microbiol v. 12, n. 3, p. 42-47, 1981.

17. PEROS, W. J.; GIBBONS, R. J. Evidence suggesting multiple binding sites in experimental pellicles for Streptococcus mutans JBP. J Dent Res v. 65, n. 6, p. 1332-1334, Oct. 1986.

18. PREUS, H. R.; OLSEN, I.; GJERMO, P. Bacteriophage infection - a possible mechanism for increased virulence of bacteria associated with rapidly destructive periodontitis. Acta Odontol Scand v. 45, n. 3, p. 49-54, Jun. 1987.
19. RENNIE, R. P.; ARBUTHNOTT, J. P. Partial characterization of Escherichia coli haemolysin. J Med Microbiol v. 7, n. 2 , p. $179-188,1974$.

20. ROSENBERG, M.; JUDES, H.; WEISS, E. Cell surface hydrophobicity of dental plaque microorganisms in situ. Infect Immun v. 42, n. 3, p. 831-834, July 1980.

21. RODENBURG, J. P.; VAN WINKELHOFF, A. J.; WINKELL, E. G. et al. Occurrence of Bacteroides gingivalis, Bacteroides intermedius and Actinobacillus actinomycetemcomitans in severe periodontitis in relation to age and treatment history. J Clin Periodontol v. 17, n. 3, p. 392-399, 1990.

22. SLOTS, J. Selective medium for Actinobacillus actinomycetemcomitans. J Clin Microbiol v. 15, n. 4, p. 606-609, 1982.

23. SLOTS, J. Salient biochemical characters of Actinobacillus actinomycetemcomitans. Arch Microbiol v. 131, n. 5, p. 60-67, Mar. 1982.

16. SUNDQVIST, G.; JOHANSSON, E. Bactericidal effect of pooled human serum on Bacteroides melaninogenicus, Bacteroides asaccharolyticus and Actinobacillus actinomycetemcomitans. Scan J Dental Res v. 90, n. 11, p. 29-36, 1982

24. STEVENS, R. H.; LILLARD, S. E.; HAMMOND, B. F. Purification and biochemical properties of a bacteriocin from Actinobacillus actinomycetemcomitans. Infect Immun v. 55, n. 4, p. 692-697, July 1987.

25. TSAI, C. C.; SHENKER, B. J.; DI RIENZO, J. M. et al. Extraction and isolation of a leukotoxin from Actinobacillus actinomycetemcomitans with polymyxin B. Infect Immun v. 43, n. 2, p. 700-705, Mar. 1984.

26. VERWEIJ-VAN VUGHT, A. M. J. J.; NAMAVAR, F.; VEL, W. A. C. et al. Pathogenic synergy between Escherichia coli and Bacteroides fragilis or Bacteroides vulgatus in experimental infections: a non-specific phenomenon. J Med Microbiol v. 21, n. 3, p. 43-47, 1986.

27. WILSON, M.; HENDERSON, B. Virulence factors of Actinobacillus actinomycetemcomitans relevant to the pathogenesis of inflammatory periodontal diseases. FEMS Microbiol Rev v. 17, n. 3, p. 365-379, Apr. 1995.

28. ZAMBON, J. J.; CHRISTERSSON, L. A.; SLOTS, J. Actinobacillus actinomycetemcomitans in human periodontal disease. J Periodontol v. 54, n. 4, p. 707-711, May 1983.

29. ZAMBON, J. J.; SLOTS, J.; MIYASAKI, K. et al. Purification and characterization of the sorotype $\mathrm{C}$ antigen from Actinobacillus actinomycetemcomitans. Infect Immun v. 44, n. 1, p. 22-27, Mar. 1984.
Recebido para publicação em 22/10/99

Enviado para reformulação em 02/11/99 Aceito para publicação em 15/02/00 